\title{
DEVELOPMENT OF DIVING CAPACITY IN EMPEROR PENGUINS
}

\author{
P. J. PONGANIS ${ }^{1}, *$ L. N. STARKE ${ }^{1}$, M. HORNING ${ }^{2}$ AND G. L. KOOYMAN ${ }^{1}$ \\ ${ }^{1}$ Center for Marine Biotechnology and Biomedicine, Scripps Institution of Oceanography, University of California, \\ San Diego, La Jolla, CA 92093-0204, USA and 2 Department of Marine Biology, Texas A\&M University, \\ 5007 Avenue U, Galveston, TX 77551, USA \\ *e-mail: pponganis@ucsd.edu
}

Accepted 8 January; published on WWW 9 March 1999

\begin{abstract}
Summary
To compare the diving capacities of juvenile and adult emperor penguins Aptenodytes forsteri, and to determine the physiological variables underlying the diving ability of juveniles, we monitored diving activity in juvenile penguins fitted with satellite-linked time/depth recorders and examined developmental changes in body mass $\left(M_{b}\right)$, hemoglobin concentration, myoglobin $(\mathrm{Mb})$ content and muscle citrate synthase and lactate dehydrogenase activities. Diving depth, diving duration and time-at-depth histograms were obtained from two fledged juveniles during the first 2.5 months after their depature from the

and $200 \mathrm{~m}$. Although most dives lasted less than $2 \mathrm{~min}$ during the 2 month period, 8-25\% of transmitted dives in the last 2 weeks lasted $2-4 \mathrm{~min}$. These values are lower than those previously recorded in adults during foraging trips. Of the physiological variables examined during chick and juvenile development, only $M_{\mathrm{b}}$ and $M b$ content did not approach adult values. In both near-fledge chicks and juveniles, $M_{\mathrm{b}}$ was $\mathbf{5 0 - 6 0} \%$ of adult values and $M b$ content was $24-31 \%$ of adult values. This suggests that the increase in diving capacity of juveniles at sea will be most dependent on changes in these factors.
\end{abstract} Cape Washingon colony in the Ross Sea, Antarctica. During this period, values of all three diving variables increased progressively. After 8-10 weeks at sea, 24-41 \% of transmitted maximum diving depths were between 80

Key words: Aptenodytes forsteri, emperor penguin, chick, citrate synthase, development, diving, haemoglobin, lactate dehydrogenase, muscle, myoglobin, satellite tracking.

\section{Introduction}

The development of diving capacity in juvenile emperor penguins (Aptenodytes forsteri) should be critical to their survival and success, especially during their first trip to sea in which they travel beyond the Antarctic Circle (Kooyman et al., 1996). However, little is known about the diving ability of juveniles or about the development of the physiological factors underlying that ability. In a study of penguin myoglobin $(\mathrm{Mb})$, Weber et al. (1974) reported extremely low to almost undetectable $\mathrm{Mb}$ concentrations in one young Adelie (Pygoscelis adeliae) and one young gentoo (Pygoscelis papua) chick, and a $\mathrm{Mb}$ concentration in a fledged Adelie chick that was $43 \%$ of the adult value. In a study of another diving bird, the pigeon guillemot (Cepphus columba), Haggblom et al. (1988) reported a similar developmental pattern for $\mathrm{Mb}$, and also found that blood hemoglobin $(\mathrm{Hb})$ concentration and pectoral muscle lactate dehydrogenase (LDH) activity had reached adult levels by the time of fledging. These studies suggest that $\mathrm{Mb}$, but not $\mathrm{Hb}$ or muscle enzyme activity, may be a critical determinant in the development of diving capacity by fledged chicks. This is especially pertinent to emperor penguins, in which the muscle $\mathrm{O}_{2}$ store constitutes $47 \%$ of the estimated total $\mathrm{O}_{2}$ store of adults (Kooyman and Ponganis, 1998). Therefore, in this study, we report diving characteristics

of juvenile emperor penguins from the Cape Washington colony $\left(74^{\circ} 32^{\prime} \mathrm{S} ; 165^{\circ} 22^{\prime} \mathrm{E}\right)$ and developmental changes in body mass $\left(M_{\mathrm{b}}\right), \mathrm{Hb}$ concentration, $\mathrm{Mb}$ content and muscle enzyme activities. Muscle LDH activity was examined as an indicator of anaerobic capacity and to determine whether the developmental changes observed in LDH activity in pigeon guillemots (Haggblom et al., 1988) also occurred in emperor penguins. Citrate synthase (CS) activity was examined as an index of aerobic capacity.

\section{Materials and methods}

Satellite-linked time/depth recorders (SLTDR, $0.25 \mathrm{~W}$, $240 \mathrm{~g}$, Wildlife Computers) were attached (Kooyman and Kooyman, 1995) to two juvenile emperor penguins Aptenodytes forsteri (Gray) at Cape Washington on 17-18 December 1996. The body masses of these birds (9068 and 9069) were 12.7 and $15.9 \mathrm{~kg}$, respectively. The time/depth recorders had a resolution of $2 \mathrm{~m}$, a dive threshold of $4 \mathrm{~m}$ and a maximum range of $500 \mathrm{~m}$. They were programmed to sample depth at $10 \mathrm{~s}$ intervals and logged data as dive duration, maximum dive depth and time at depth. Upon satellite (NOAA) link, 6h histogram data were transmitted. 
Blood samples and pectoral muscle biopsy specimens were obtained using aseptic techniques from chicks in the Cape Washington colony on 31 October, 24 November and 14 December 1994, from post-molt captive juveniles in late January 1995, and from adult birds captured near the McMurdo Sound ice-edge in October-December during two field seasons. This protocol was approved by the UCSD Animal Subjects Committee and was conducted under an Antarctic Conservation Act permit. Blood samples were obtained using a syringe and 22 gauge needle from wing or foot veins of restrained chicks. Muscle biopsies (Ponganis et al., 1997) were performed under local anesthesia (2\% lidocaine) in chicks. Both blood and muscle samples were obtained from adult birds under general anesthesia (Ponganis et al., 1997). Sample preservation and assays for $\mathrm{Hb}$ concentration, $\mathrm{Mb}$ content, $\mathrm{CS}$ activity and LDH activity were as described by Ponganis et al. (1997). All birds were weighed to the nearest $50 \mathrm{~g}$ using an Ohaus electronic load scale.

To evaluate initial diving behavior of fledged chicks and to examine biochemical variables in post-molt juveniles, chicks from the Cape Washington colony were captured on 20-21 December 1994 and transported by Twin Otter plane to a seaice camp near McMurdo Station. These birds were fed fish at a rate approximately $20-25 \%$ of their body mass per day. They initially received Antarctic cod (Dissostichus mawsoni), but by the eighth day, the diet was completely herring (Clupea harengas). During this time, the birds were allowed access to isolated dive holes ( $2 \mathrm{~m}$ diameter). They were released at the McMurdo ice-edge at the end of January.

In this study, we consider chicks to be birds prior to the completion of the molt of the downy feathers and before their first entry into the sea. Juveniles are fledged birds that have departed from the colony and begun to swim. At the time of departure from the colony, the birds may not yet have lost all their downy feathers.

One-way analysis of variance (ANOVA) and Tukey comparison of means (Statistica, Statsoft) were conducted to compare variables measured in different groups. Differences were assumed to be significant at $P<0.05$. Graphical analyses were performed using Origin 4.1 (Microcal) and Quatro Pro (Corel). Values are expressed as means \pm S.D. unless indicated otherwise.

\section{Results}

The first transmissions from the two juveniles equipped with SLTDRs were received during the week of 18 December 1996. Transmissions continued for a 2.5 month period. The number of successfully transmitted histograms of each data category varied weekly. Histograms of maximum depth of dive, diving duration and time at depth are presented in weekly intervals in Figs 1-3. Data transmissions were not successfully received during the week of 25-31 December; therefore, that week (week $B$ ) is omitted from all figures.

During this entire 10 week period, $33 \%$ and $34 \%$ of dives of penguins 9068 and 9069 , respectively, were less than $10 \mathrm{~m}$
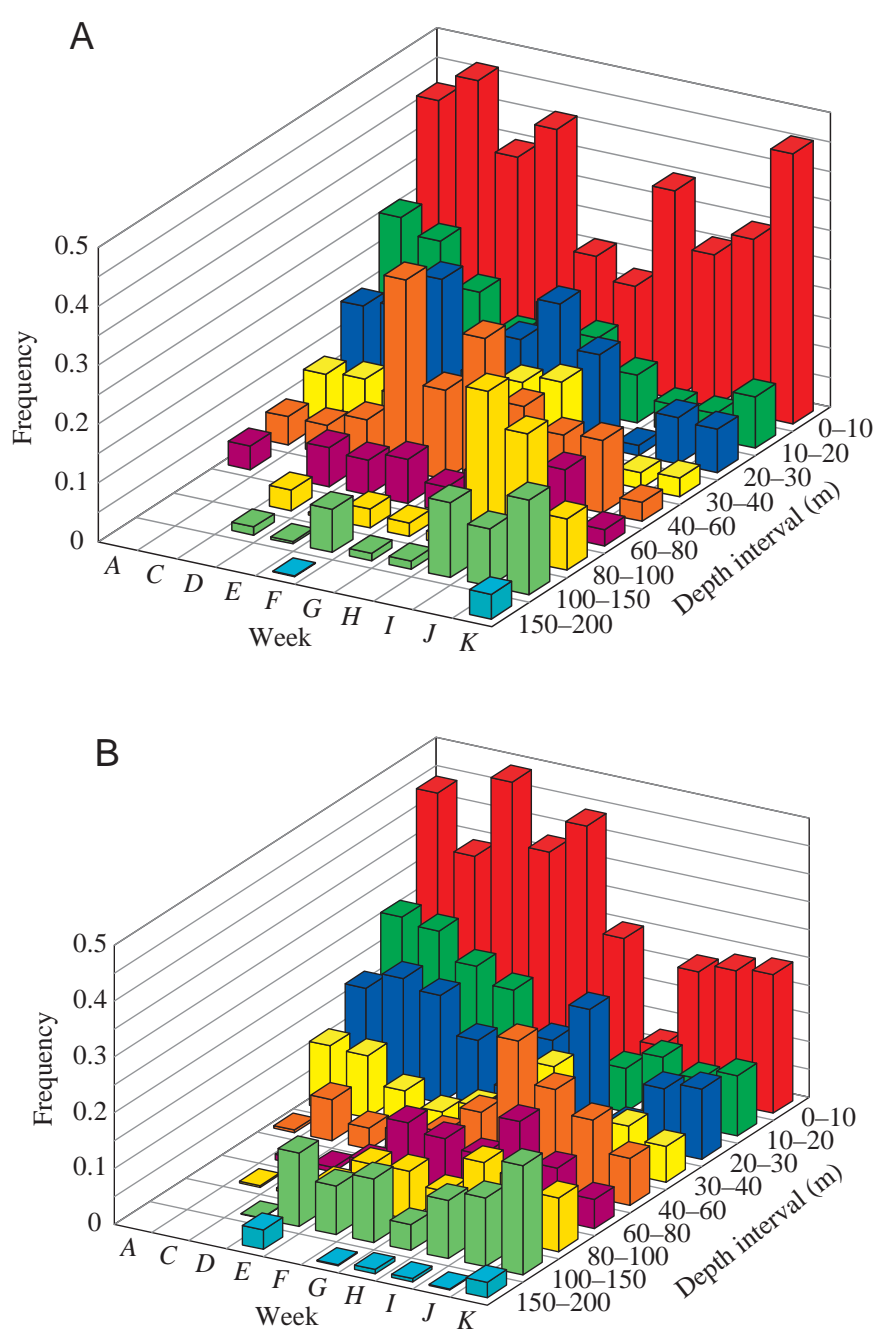

Fig. 1. Weekly distribution (weeks $A-K$ ) of diving depths from transmitted maximum depth-of-dive histograms from juvenile emperor penguins 9068 (A) and 9069 (B). Week $A$ begins on 18 December 1996. Frequency indicates fraction of maximum depths in a given depth interval. No transmissions were received in the second week, which is omitted from the figure.

in depth, $25 \%$ and $28 \%$ of all diving durations were less than $0.5 \mathrm{~min}$, and $68 \%$ of time at depth was at depths less than $10 \mathrm{~m}$. However, by the tenth week, $20-23 \%$ of dives were between 100 and $200 \mathrm{~m}$ in depth, $17-25 \%$ of diving durations were between 2 and $4 \mathrm{~min}$, and $4-10 \%$ of the time at depth was between 150 and $200 \mathrm{~m}$. During the 10 weeks, the total numbers of dive depth, dive duration and time at depth values transmitted were 5934 and 8509 depths, 6237 and 8611 durations, and 29250 and 52140 s for birds 9068 and 9069 , respectively.

Body mass, $\mathrm{Hb}$ concentration and $\mathrm{Mb}$ content were all determined in four cohorts of young birds (Fig. 4). Groups of five chicks at Cape Washington were captured and sampled on 31 October, 24 November and 14 December; four post-molt juvenile birds were sampled on 30 January. Hemoglobin concentration and myoglobin content were also measured in 

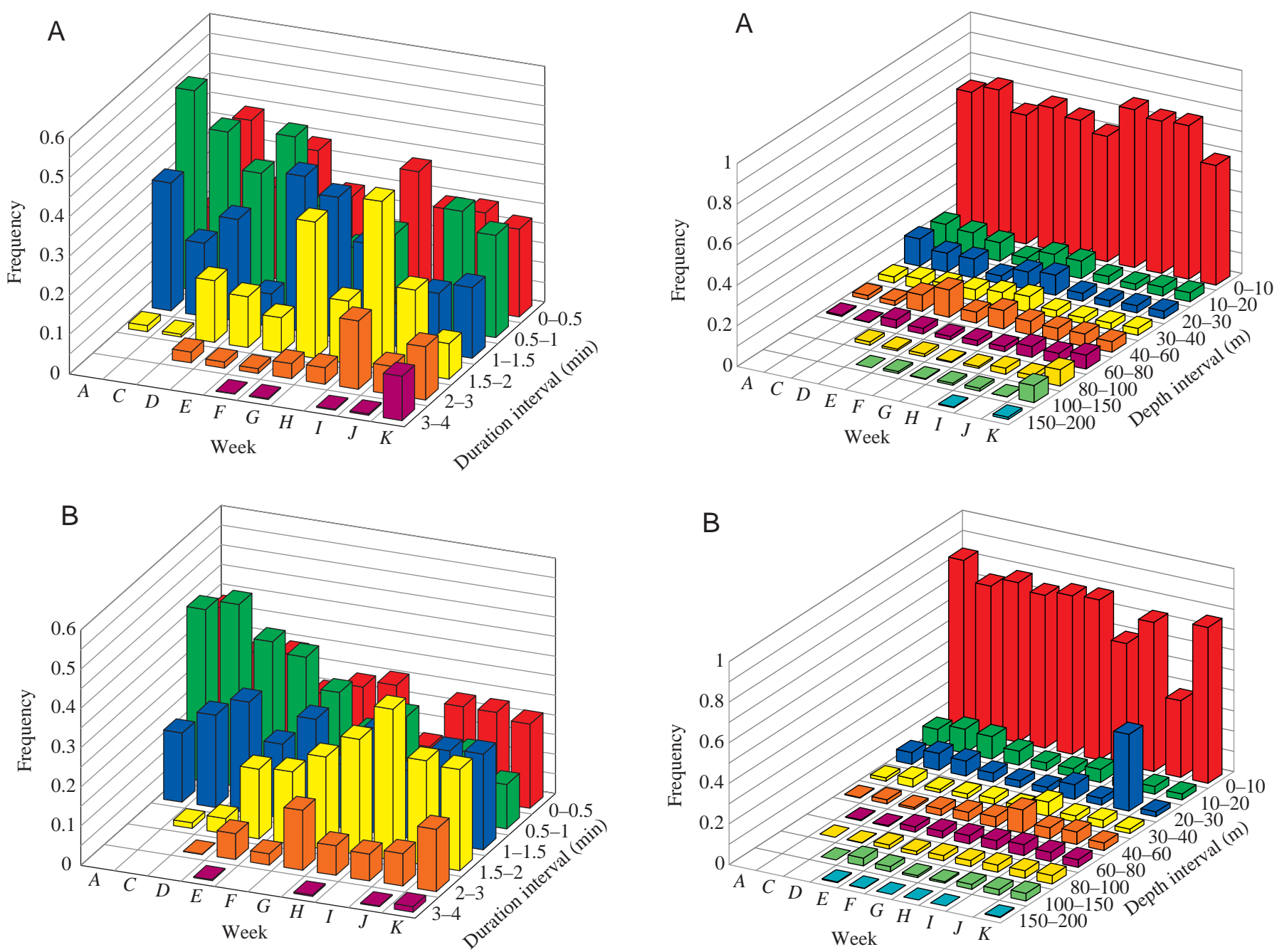

Fig. 2. Weekly distribution (weeks $A-K$ ) of diving durations from transmitted duration histograms from juvenile emperor penguins 9068 (A) and 9069 (B). Frequency indicates fraction of dive durations within a duration interval. Weekly intervals are as in Fig. 1.

four and six adult birds, respectively (Fig. 4). Although both biochemical variables increased progressively during development (ANOVA: $\mathrm{Hb}, F=53.7, P<0.001 ; \mathrm{Mb}, F=157.9$, $P<0.001)$, only the $\mathrm{Hb}$ concentration in post-molt, captive

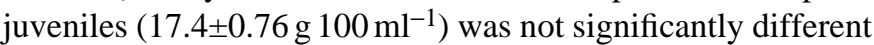

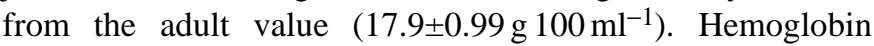
concentration in pre-molt (14 December) chicks was $13.5 \pm$

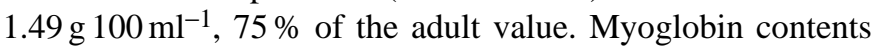

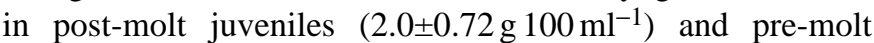
chicks $\left(1.5 \pm 0.22{\left.\mathrm{~g} 100 \mathrm{ml}^{-1}\right)}^{-1}\right.$ were only $31 \%$ and $24 \%$,

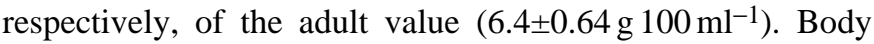
masses of both pre- (14 December) and post-molt penguins were significantly different from adult body masses (ANOVA: $F=202.0, P<0.001)$; they were approximately $60 \%$ of the adult value (Fig. 4). During captivity, the juveniles had gained $4.0 \pm 1.01 \mathrm{~kg}$ prior to biopsy on 30 January.

Enzyme activities were measured in three groups of birds. The pre-molt chicks were the five birds sampled on 14 December at

Fig. 3. Weekly distribution (weeks $A-K$ ) of time at depth from transmitted histograms from juvenile emperor penguins 9068 (A) and 9069 (B). Frequency indicates the fraction of time at a given depth interval. Weekly intervals are as in Fig. 1.

Cape Washington, the post-molt juveniles were four captive birds sampled between 16 and 30 January, and the adult group consisted of seven birds. Although CS activity was greatest in adult birds $\left(33.3 \pm 6.47 \mu \mathrm{mol} \mathrm{g}^{-1} \mathrm{~min}^{-1}\right)$, it was not significantly different (ANOVA: $F=2.95, P=0.09$ ) from those of preand post-molt birds $\left(23.0 \pm 7.74 \mu \mathrm{mol} \mathrm{g}^{-1} \mathrm{~min}^{-1}\right.$ and $25.5 \pm 8.38 \mu \mathrm{mol} \mathrm{g}^{-1} \mathrm{~min}^{-1}$, respectively). LDH activities were not significantly different (ANOVA: $F=3.21, P=0.07$ ) in the three groups $\left(755 \pm 201 \mu \mathrm{mol} \mathrm{g}^{-1} \mathrm{~min}^{-1}, 992 \pm 114 \mu \mathrm{mol} \mathrm{g}^{-1} \mathrm{~min}^{-1}\right.$ and $881 \pm 96 \mu \mathrm{mol} \mathrm{g}^{-1} \mathrm{~min}^{-1}$, respectively, in pre-molt, post-molt and adult birds). The body masses of the pre- and post-molt birds $(14.2 \pm 0.72 \mathrm{~kg}$ and $14.1 \pm 1.54 \mathrm{~kg}$, respectively) were $56 \%$ of that of the adults $(25.1 \pm 1.29 \mathrm{~kg})$. By the time of biopsy, the post-molt juveniles had gained $2.0 \pm 1.09 \mathrm{~kg}$ during their captivity.

Starting on 1 January, the captive chicks were allowed access to a dive hole for $3 \mathrm{~h}$ per day. Diving behavior among the birds was highly variable in duration of activity and in number of dives. This may have been due to poor underwater 


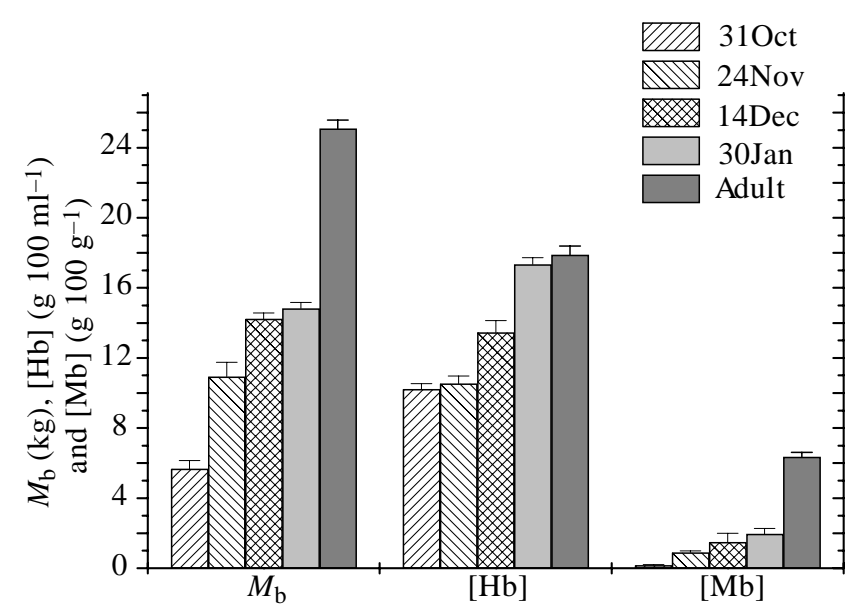

Fig. 4. Developmental changes in body mass $\left(M_{\mathrm{b}}\right)$, hemoglobin $(\mathrm{Hb})$ concentration and myoglobin $(\mathrm{Mb})$ concentration in emperor penguin chicks (31 October, 24 November and 14 December; $N=5$ ) and juveniles (30 January; $N=4$ ) in comparison with adult values $(\mathrm{Hb}$, $\left.N=4 ; \mathrm{Mb}, N=6 ; M_{\mathrm{b}}, N=7\right)$. Hatching usually occurs between late July and early August. On 14 December, the chicks had not yet completely molted, but may be considered to be at an early juvenile stage as this is the approximate week at which they would normally have entered the water. Values are means + S.E.M.

visibility $(<5 \mathrm{~m})$ and to harassment by Weddell seals (Leptonychotes weddellii). The diving durations of three animals on 8-10 January ranged from 5 to $20 \mathrm{~s}(N=29)$. By 25-26 January, observed diving durations for these three birds ranged from 13 to $275 \mathrm{~s} \quad(N=19)$, with maximum diving durations of 2.7-3.5 min for each bird.

\section{Discussion}

The dive histogram data for the two juvenile penguins do not represent a complete record of all dives during this period because of missed transmissions by the NOAA satellite, but they provide a first sampling of the diving depths and durations of juvenile penguins during their initial months at sea. The greatest proportions of dives were less than $10 \mathrm{~m}$ in depth and $1 \mathrm{~min}$ in duration (Figs 1-3). The majority of such dives may be traveling dives. However, since the captive juvenile penguins showed a keen interest in amphipods at the isolated dive hole, some of these shallow dives are probably associated with near-surface feeding on euphausids and amphipods. All three sets of histogram data indicate that more longer and deeper dives occurred as the chicks increased in age. These deeper dives are presumably feeding dives and demonstrate the ability of young emperor penguins to exploit prey at ever greater depths. Although depths and durations of dives increase impressively throughout this 2.5 month period, maximum depths are less than $200 \mathrm{~m}$ and maximum durations are less than 4 min. Adult emperor penguins (Kooyman and Kooyman, 1995) and even adult king penguins (A. patagonicus; Kooyman et al., 1992), which are of similar body mass to the juvenile emperor penguins, clearly have greater maximum diving depths and durations. However, the depths reached by the juvenile emperor penguins in the present study are greater than the range of foraging depths of all other species of penguins in this region except for king penguins.

Differences between adults and chicks in $M_{b}$, age, $\mathrm{O}_{2}$ stores and control of cardiovascular regulation during apnea may account for the greater diving ability of adult birds. Near the time of fledging, chick $M_{\mathrm{b}}$ is $50-60 \%$ of that in adults. Attendant differences in metabolic rate and in heat loss could contribute to the shorter diving durations and shallower diving depths of juvenile birds. This argument has been applied to observed correlations between $M_{\mathrm{b}}$ and diving durations in yearling, subadult and adult northern elephant seals (Mirounga angustirostris), Galapagos fur seals (Arctocephalus galapagoensis) and Weddell seals (Thorson and LeBoeuf, 1994; Horning and Trillmich, 1997a,b; Burns and Castellini, 1996). However, these previous studies have also indicated that initial changes in the diving durations of very young pups correlated best with age. In northern elephant seals and Galapagos fur seals, this was attributable to greater increases in $\mathrm{O}_{2}$ storage indices than in body mass (Thorson and Le Boeuf, 1994; Horning and Trillmich, 1997a). In addition, in northern elephant seals, resting metabolic rates decreased as the pups aged, despite relatively constant or decreasing body masses (Thorson and LeBoeuf, 1994). Better control of cardiovascular regulation in older pups may also contribute to these findings in seals (Castellini et al., 1994).

If one accepts that most egg-hatching occurs in emperor penguins between late July and early August, then the birds utilized in our $\mathrm{Hb}$ and $\mathrm{Mb}$ studies were approximately 3, 3.8, 4.5 and 6 months of age. Over this period, $\mathrm{Hb}$ concentration

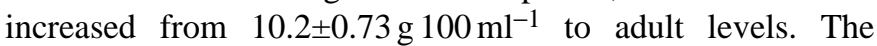
myoglobin content of the pectoral muscle increased approximately tenfold over this period, but was still, at 6 months of age, only $31 \%$ of the adult value.

Since $\mathrm{Mb}$ content (Fig. 4) and the resulting pectoral muscle $\mathrm{O}_{2}$ capacity of near-fledge chicks is only one-third of that in adult emperor penguins, we propose that this low $\mathrm{Mb}$ concentration is the major factor limiting $\mathrm{O}_{2}$ storage and the diving ability of juvenile emperor penguins. This is supported by two facts. First, $\mathrm{Hb}$ concentration in 6-month-old juveniles approaches that in adults (Fig. 4). Second, although we did not measure blood volume $\left(V_{\mathrm{b}}\right)$ in chicks, $V_{\mathrm{b}}$ is not significantly elevated in adult emperor penguins (Ponganis et al., 1997). In comparison with other birds, the mass-specific $V_{\mathrm{b}}$ of the emperor penguin is only at the upper end of the avian range of values and, indeed, is lower than those in ducks and loons (Bond and Gilbert, 1958). This contrasts with the exceptional two- to threefold elevations in $V_{\mathrm{b}}$ of pinnipeds (Kooyman, 1989). Therefore, although mass-specific $V_{\mathrm{b}}$ of chicks may be lower than that of adults, we doubt that it would be so low as to reduce the $\mathrm{O}_{2}$ stores of chick blood to only one-third of the adult value. Furthermore, muscle is the largest component of the $\mathrm{O}_{2}$ stores in adult emperor penguins; the pectoralissupracoracoideus muscle complex alone can store $19 \%$ more $\mathrm{O}_{2}$ than the entire blood volume (Ponganis et al., 1997). 
Pectoral muscle CS and LDH activities of pre-molt chicks and post-molt juveniles were not significantly different from those of adults; however, CS activity was greater in adults. This is not unexpected since oxidative enzyme activities increase with exercise and training (Holloszy and Booth, 1976), and the chicks (i.e. the pre-molt chicks) had not swum. The CS activity of pre-molt chicks was $69 \%$ of the adult value. By comparison, the $\mathrm{Mb}$ content of those chicks was only $24 \%$ of the adult value. Thus, the increase in Mb concentration lags behind the development of oxidative and glycolytic enzyme capacities. The LDH activity of the near-fledge emperor penguins was similar to that of adults. As in the pigeon guillemot (Haggblom et al., 1988), it appears that anaerobic capacity (at least as indicated by LDH activity) had reached adult levels by the time of fledging.

The developmental pattern of increasing $\mathrm{Mb}$ concentration that we have measured in emperor penguin chicks is probably typical of all penguins (Weber et al., 1974) and, perhaps, of all diving birds (Haggblom et al., 1988). At the time of fledging in all species examined, Mb content, in contrast to $\mathrm{Hb}$ concentration and muscle enzyme activities, is still only $24-43 \%$ of the adult value. The development of muscle $\mathrm{O}_{2}$ stores in seals, in contrast, appears to be more rapid. By 1 month of age in Baikal seals (Phoca sibirica), $\mathrm{Mb}$ concentration is $60 \%$ of the adult value (Neshumova et al., 1983; Petrov, 1985). Even in the seventh month, Baikal seal

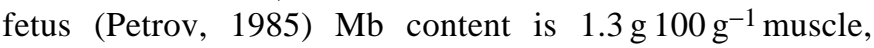
nearly equivalent to that of the 4.5-month-old emperor chick. Similarly, Mb content in nursing elephant seal pups (2-4 weeks of age) is already $33 \%$ of the adult value (Thorson, 1993; Thorson and LeBoeuf, 1994), and in seals at 12-14 weeks of age, when pups make their first foraging trips to sea, $\mathrm{Mb}$ content is $76 \%$ of the adult value. Thus, at the time of the animal's first trip to sea, it appears that the propulsive muscle of the elephant seal is better prepared in terms of $\mathrm{O}_{2}$ storage capacity than that of the emperor penguin. Although high $\mathrm{Mb}$ concentrations in grey seals (Halichoerus grypus) are associated with high Mb mRNA levels (Weller et al., 1986), the mechanisms underlying the regulation of $\mathrm{Mb}$ production in these species are unknown. Changes in $\mathrm{Mb}$ content may be related to age, exercise activity and/or exposure to tissue hypoxia (Garry et al., 1996; Holloszy and Booth, 1976; Terrados et al., 1990; Underwood and Williams, 1987). It is notable that elephant seal pups, in contrast to penguin chicks, frequent the surf between 4 and 12 weeks of age and that, during this period, submersion times increase threefold to approximately $6 \mathrm{~min}$ (Thorson and LeBoeuf, 1994).

In summary, we have examined five physiological indices during the development of emperor penguin chicks. Near the time of fledging (i.e. in pre-molt chicks and young juveniles), $\mathrm{Hb}$ concentration and muscle CS and LDH activities approached adult values. However, $M_{\mathrm{b}}$ was only $50-60 \%$ and Mb content only $24-31 \%$ of the corresponding adult values. We expect that changes in diving capacity of juvenile penguins during the first 1-2 years at sea will be most dependent on changes in these latter two factors. The diving depth and duration data of juvenile emperor penguins during their first 2.5 months at sea are consistent with this hypothesis and indicate that most dives are less than $100 \mathrm{~m}$ in depth and $2 \mathrm{~min}$ in duration. Adult emperor penguins, which have a greater $M_{\mathrm{b}}$ and higher $\mathrm{Mb}$ content, and adult king penguins, which have a similar body mass but a higher Mb content (Baldwin et al., 1984), both have greater diving capacities than juvenile emperor penguins.

This research was supported by NSF grant OPP 92-19872.

\section{References}

Baldwin, J., Hardel, J-P., Montagues, T. and Tomkin, R. (1984). Energy metabolism in penguin swimming muscles. Mol. Physiol. 6, 33-42.

Bond, C. F. and Gilbert, P. W. (1958). Comparative study of blood volume in representative aquatic and nonaquatic birds. Am. J. Physiol. 194, 519-521.

Burns, J. M. and Castellini, M. A. (1996). Physiological and behavioral determinants of the aerobic dive limit in Weddell seal (Leptonychotes weddellii) pups. J. Comp. Physiol. B 166, 473-483.

Castellini, M. A., Rea, L. D., Sanders, J. L., Castellini, M. A. and Zenteno-Savin, T. (1994). Developmental changes in cardiorespiratory patterns of sleep-associated apnea in northern elephant seal pups. Am. J. Physiol. 267, R1294-R1301.

Garry, D. J., Bassel-Duby, R. S., Richardson, J. A., Grayson, J., Neufer, P. D. and Williams, R. S. (1996). Postnatal development and plasticity of specialized muscle fiber characteristics in the hindlimb. Dev. Genet. 19, 146-156.

Haggblom, L., Terwilliger, R. C. and Terwilliger, B. (1988). Changes in myoglobin and lactate dehydrogenase in muscle tissues of a diving bird, the pigeon guillemot, during maturation. Comp. Biochem. Physiol. 91B, 273-277.

Holloszy, J. O. and Booth, F. W. (1976). Biochemical adaptations to endurance exercise in muscle. Annu. Rev. Physiol. 38, 273-291.

Horning, M. and Trillmich, F. (1997a). Development of hemoglobin, hematocrit and erythrocyte values in Galapagos fur seals. Mar. Mammal. Sci. 13, 100-113.

Horning, M. and Trillmich, F. (1997b). Ontogeny of diving behaviour in the Galapagos fur seals. Behaviour 134, 1211-1257.

Kooyman, G. L. (1989). Diverse Divers. Berlin: Springer Verlag. 200pp.

Kooyman, G. L., Cherel, Y., Lemaho, Y., Croxall, J. P., Thorson, P. H., Ridoux, V. and Kooyman, C. A. (1992). Diving behavior and energetics during foraging cycles in king penguins. Ecol. Monogr. 62, 143-163.

Kooyman, G. L. and Kooyman, T. G. (1995). Diving behavior of emperor penguins nurturing chicks at Coulman Island, Antarctica. Condor 97, 536-549.

Kooyman, G. L., Kooyman, T. G., Horning, M. and Kooyman, C. A. (1996). Penguin dispersal after fledging. Nature 383, 397.

Kooyman, G. L. and Ponganis, P. J. (1998). The physiological basis of diving to depth: birds and mammals. Annu. Rev. Physiol. 60, 19-32.

Neshumova, T. V., Cherapanova, V. A. and Petrov, E. A. (1983). Myoglobin concentration in muscles of the seal Pusa sibirica. Zh. Evol. Biochem. Physiol. 19, 93-95. 
Petrov, E. A. (1985). Myoglobin concentration and distribution in the tissue of foetal Baikalian seal (Phoca sibirica). Zh. Evol. Biochem. Physiol. 21, 83-86.

Ponganis, P. J., Costello, M. L., Starke, L. N., Mathieu-Costello, O. and Kooyman, G. L. (1997). Structural and biochemical characteristics of locomotory muscles of emperor penguins, Aptenodytes forsteri. Respir. Physiol. 109, 73-80.

Terrados, N., Jansson, E., Sylven, C. and Kaijser, L. (1990). Is hypoxia a stimulus for synthesis of oxidative enzymes and myoglobin. J. Appl. Physiol. 68, 2369-2372.

Thorson, P. H. (1993). Development of diving in the northern elephant seal. PhD thesis, University of California, Santa Cruz. 210pp.

Thorson, P. H. and LeBoeuf, B. J. (1994). Developmental aspects of diving in northern elephant seal pups. In Elephant Seals: Population Ecology, Behavior and Physiology (ed. B. J. LeBoeuf and R. M. Laws), pp. 271-289. Berkeley: University of California Press.

Underwood, L. E. and Williams, R. S. (1987). Pretranslational regulation of myoglobin gene expression. Am. J. Physiol. 252, C450-C453.

Weber, R. E., Hemmingsen, E. A. and Johansen, K. (1974). Functional and biochemical studies of penguin myoglobin. Comp. Biochem. Physiol. 49B, 197-214.

Weller, P. A., Price, M., Isenberg, H., Edwards, Y. H. and Jeffreys, A. A. (1986). Myoglobin expression: early induction and subsequent modulation of myoglobin and myoglobin mRNA during myogenesis. Mol. Cell. Biol. 6, 4539-4547. 